DOI: $10.11649 /$ abs.2018.006

\author{
Alvydas Nikžentaitis \\ Instytut Historii Litwy \\ Wilno \\ alvydas.nikzentaitis@istorija.lt
}

\title{
Kultura pamięci i polityka historyczna w dzisiejszej Rosji
}

\section{Wstęp}

Niemal codziennie w światowych mediach pojawiają się informacje na temat stosunku Rosji do własnej przeszłości, która jest ważnym elementem zarówno jej kultury pamięci, jak i polityki historycznej. W Rosji, a także poza jej granicami, opublikowano już wiele prac poświęconych tej problematyce. Napisanie na ten temat czegoś nowego przysparza pewnych trudności. Z drugiej strony jednak podczas analizowania problematyki badania kultury pamięci i polityki historycznej współczesnej Rosji, wyraźnie widać brak dialogu dyskursów historiograficznych. O ile środowiska naukowe starają się zwracać uwagę na publikacje anglojęzyczne, to badacze rosyjscy zupełnie ignorują ogromny dorobek autorów niemieckich, a ci ostatni w niedostateczny sposób sięgają po opracowania rosyjskie. A przecież już samo zestawienie i porównanie badań zrealizowanych przez wymienione wyżej szkoły badawcze, daje nadzieję na odkrycie nowych aspektów stosunkowo dobrze zbadanego zagadnienia.

Temat Rosji interesuje mnie w specyficzny sposób. Poniższy tekst jest częścią większego projektu badań porównawczych kultur pamięci Rosji, Niemiec, Polski,

This is an Open Access article distributed under the terms of the Creative Commons Attribution 3.0 PL License (creativecommons.org/licenses/by/3.0/pl/), which permits redistribution, commercial and non-commercial, provided that the article is properly cited. (c) The Author(s) 2018. (c) To Polish translation: Małgorzata Kasner 2018.

Publisher: Institute of Slavic Studies, Polish Academy of Sciences

[Wydawca: Instytut Slawistyki Polskiej Akademii Nauk] 
Litwy, Białorusi i Ukrainy ${ }^{1}$. Ujmując skrótowo, jego celem jest próba odkrycia mechanizmów formowania (się) kultury pamięci i polityki historycznej, a także ukazanie potencjalnej specyfiki tych zagadnień w poszczególnych krajach. Mimo iż projekt badawczy rozpoczął się dopiero w 2017 roku, w końcowej części artykułu spróbuję jednak zaprezentować pewne konkretne wnioski z jego realizacji. W niniejszym artykule świadomie (także z powodu braku miejsca) nie zajmuję się prezentacją podstawowych teorii związanych z powyższą problematyką, ograniczając się jedynie do kilku niezbędnych uwag teoretycznych, warunkujących główne pytania, na które postaram się poszukać odpowiedzi:

1. Dość powszechnie panująca teza, że w danym kraju nie ma jednej kultury pamięci i że można mówić jedynie o wielu paralelnie istniejących i często konkurujących ze sobą wielkich narracjach (Cornelißen, 2012), sprawia, że na świecie niemal nie prowadzi się badań porównawczych na ten temat. W niniejszym artykule empirycznie zostanie zbadana zasadność takiego założenia teoretycznego.

2. Na podstawie materiału rosyjskiego zostanie przeanalizowane, wynikające $\mathrm{z}$ dotychczasowych badań nad kulturą pamięci Litwy, twierdzenie autora artykułu o ciągłej transformacji elementów kultury pamięci jako warunku niezbędnego dla jej istnienia (Nikžentaitis \& Čepaitienè, 2014, ss. 115-130).

3. Będą poszukiwane analogie i różnice między kulturami pamięci a politykami historycznymi Rosji oraz wybranych państw regionu Europy Środkowo-Wschodniej.

Stefan Troebst, analizując kultury pamięci krajów postkomunistycznych i ich związek z komunizmem, zaliczył Rosję i Białoruś do grupy państw, które najmniej odeszły się od tradycji komunistycznej (Troebst, 2005). Oczywiście, poszczególne elementy takiej tezy autora, wynikające z dość dużego stopnia uogólnienia, można by poddać krytyce, jednak samo zwrócenie uwagi na ten problem, zmusza do dokładniejszego, niźli w wypadku innych krajów postkomunistycznych, przyjrzenia się potencjalnym związkom kultury pamięci dzisiejszej Rosji z tradycją sowiecką (komunistyczną).

Jak wiadomo, w ostatnich dziesięcioleciach istnienia Związku Radzieckiego jego kultura pamięci opierała się na trzech mitach: Wielkiej Socjalistycznej Rewolucji Październikowej, zwycięstwa w Wielkiej Wojnie Ojczyźnianej i micie postępu. Dlatego też należy prześledzić, jakie miejsce zajmują one we współczesnej kulturze pamięci Rosji.

${ }^{1}$ Badanie pt. Tapatybiu modernizacija? „Europeizacijos”, nacionalizmo ir postsovietizmo iššūkiai atminties kulturom (Modernizacja tożsamości? Wyzwania „europeizacji”, nacjonalizmu i postsowietyzmu wobec kultur pamięci) finansuje Lietuvos mokslo taryba (pol. Litewska Rada Naukowa), umowa MOD-17006. 


\section{Losy mitów sowieckich we współczesnej Rosji}

Kultura pamięci jest w istotny sposób powiązana z polityką i dlatego zmiany w strukturze społecznej wywierają na nią szczególnie duży wpływ (A. Assmann \& Shortt, 2012, ss. 6-7). Widać to wyraźnie także w przypadku Rosji. Pierwsze zmiany w kraju rozpoczęły się jeszcze w czasach Związku Radzieckiego, w okresie tzw. pierestrojki. Nietrudno przewidzieć, że z oczywistych powodów pierwszą ofiarą przemian stał się mit postępu. I choć współczesna Rosja ciągle ceni osiągnięcia okresu sowieckiego, to jednak mit postępu w państwowej kulturze pamięci nie odgrywa już istotnej roli.

O wiele bardziej skomplikowany był proces funkcjonowania pozostałych mitów, których dekonstrukcja rozpoczęła się w drugim etapie pierestrojki, zapoczątkowanym w 1989 roku.

Należy podkreślić, że mit rewolucji październikowej zintegrował ze sobą nie tylko kult Lenina, ale nieco później także kult Stalina. Z tego powodu stosunek rosyjskiego społeczeństwa do tego mitu był dość skomplikowany. Społeczeństwo pamiętało antystalinowskie inicjatywy sekretarza Komunistycznej Partii Związku Radzieckiego (dalej cyt. KPZR) Nikity Chruszczowa, dlatego nie budzi zdziwienia fakt, że już na samym początku pierestrojki ponownie dało się słyszeć głosy potępiające kult Stalina. Michaił Gorbaczow odniósł się do nich, ostro krytykując stalinizm, podczas plenum w styczniu 1987 roku. Pod koniec tego samego roku, po skrytykowaniu przez Gorbaczowa breżniewowskiej polityki wobec Stalina, wznowiono proces rehabilitacji ofiar stalinizmu. Pierwszą osobą zrehabilitowaną podczas pierestrojki (1988) był Nikołaj Bucharin i na nim ten proces się nie zatrzymał (Шерлок,2014, ss. 69-74). O ile z powodu uformowanej w Związku Radzieckim tradycji krytyka kultu Stalina nie zderzyła się z poważniejszymi trudnościami, o tyle w przypadku Lenina ruszenie go z piedestału było o wiele trudniejsze. Po pierwsze, przeszkadzały w tym ideologiczne podstawy pierestrojki. Inicjując ją, Gorbaczow apelował o powrót do tradycji leninowskich. W dziedzinie ekonomii przykładem dla przeprowadzanych przez niego reform była realizowana przez Władimira I. Lenina nowa polityka ekonomiczna (w skrócie NEP) (Шерлок, 2014, ss. 95-98). Otwarta krytyka Lenina rozpoczęła się właśnie w roku 1988.

Jednym z pierwszych krytyków stał się ekspert ds. ekonomii, dziennikarz Wasilij Seliunin, który w jednym ze swoich artykułów z jednej strony chwalił Lenina za prowadzenie NEP-u, z drugiej zaś ostro krytykował jego politykę wobec chłopów. Ponadto oskarżył pierwszego przywódcę Związku Radzieckiego, że wspólnie z Trockim i Dzierżyńskim stworzyli system obozów koncentracyjnych (Селюнин, 1988, ss. 162-189). W ten sposób rok 1988 stał się początkiem krytycznego dyskursu wobec Lenina. Jednakże inaczej niż w przypadku Stalina, w tej sprawie nie było porozumienia ani w społeczeństwie, ani w partyjnych elitach. W szeregach obrońców Lenina pozostał także Gorbaczow. Jednak już wtedy wyraźnie się zarysowała twarda antyleninowska pozycja członka Biura Politycznego KPZR Aleksandra Jakowlewa (Шерлок, 2014, ss. 
111, 184-185, 198). Tak oto w okresie sowieckim sprawa Lenina nie została ostatecznie załatwiona. Sposobów na jej rozwiązanie należało szukać dopiero po rozpadzie Związku Radzieckiego, już w niepodległej Rosji.

Nowym impulsem do rezygnacji z kolejnego mitu sowieckiego - mitu rewolucji październikowej - był nieudany pucz z 1991 roku. Duża część społeczeństwa rosyjskiego, która nie poparła puczystów, zinterpretowała próbę przejęcia władzy jako chęć powrotu do czasów Związku Radzieckiego sprzed pierestrojki. Po upadku puczu, pierwszy prezydent Rosji dążył nawet do prawnego zakazania działalności KPZR (Plaggenborg, 2002, s. 577). Proces sądowy okazał się w istocie przegraną prezydenta Jelcyna. I chociaż w ostatecznym werdykcie sądowym przyznano, że KPZR bezprawnie zarządzała majątkiem państwowym, to jednak samej partii nie uznano za organizację przestępczą (Копосов, 2011, ss. 131-133).

Abstrahując od nieskutecznej próby rozrachunku z KPZR, retoryka elit rządzących była jawnie antykomunistyczna. Zrozumiałe jest, że wiele uwagi poświęcano w niej także rewolucji październikowej. Narracja oficjalna, która uformowała się w ostatnim dziesięcioleciu XX wieku, traktowała to wydarzenie jako tragedię, z której konsekwencjami ostatecznie musi poradzić sobie współczesna Rosja (Малинова, 2015, s, 46). Z drugiej strony, wprowadzane w życie radykalne reformy ekonomiczne rozbiły polityczną elitę nowej Rosji. Władzę rosyjskiego prezydenta zaczęła znacząco ograniczać opozycja, wśród której najważniejszą siłą polityczną stała się nowo utworzona Komunistyczna Partia Rosji. Za sprawą opozycji ruch antyleninowski w Rosji poniósł klęskę. Borys Jelcyn musiał się liczyć z opozycją polityczną nawet wówczas, gdy rozwiązał parlament i mógł wybierać jedynie pośrednie metody dekonstrukcji mitu rewolucji październikowej (Пихоя, 2007, ss. 395-484). Decyzją prezydenta z 1994 roku została zmieniona nazwa święta państwowego związanego z wybuchem rewolucji październikowej. Od tego czasu miał to być Dzień Zgody i Harmonii (Lutz-Auras, 2013, s. 254), jednak Jelcynowi i tak nie udało się usunąć Lenina z mauzoleum (choć takie plany istniały) (Sygar, 2016, s. 17). Mogłoby się wydawać, że święto 7 listopada ostatecznie zniknęło z kalendarza rosyjskich świąt państwowych w 2004 roku, kiedy decyzją prezydenta Władimira Putina to 4 listopada stał się nowym dniem świątecznym - Dniem Jedności Narodowej Rosji (Ефремова, 2013, ss. 286-300). Tak się jednak nie stało. Już w następnym, 2005 roku, z inicjatywy jednego z komitetów Dumy Państwowej, 7 listopada został włączony do kalendarza dni pamięci. Co prawda, nie jako dzień „Wielkiej Socjalistycznej Rewolucji Październikowej”, a jako dzień „rewolucji październikowej 1917 roku" (Малинова, 2015, s. 77).

W rzeczy samej, w procesie ponownej interpretacji wydarzeń rewolucji październikowej nie należy bagatelizować roli nowo utworzonej Komunistycznej Partii Rosji. To właśnie jej przedstawicielom udało się zaprezentować rosyjskiemu społeczeństwu nowy, łatwy do zaakceptowania wizerunek symbolu przeszłości komunistycznej. W nowej interpretacji paradygmat walki klasowej został zastąpiony nacjonalistycz- 
nym. Rewolucja październikowa, uniemożliwiając Zachodowi zapanowanie nad Rosją, stała się symbolem zderzenia cywilizacji rosyjskiej ze światem zachodnim. $\mathrm{Na}$ dodatek rewolucja była uważana za ucieleśnienie rosyjskiego ducha narodowego oraz najważniejszych cech rosyjskiego charakteru narodowego (Малинова, 2015, s. 77). Takie wartościowanie stworzyło Rosjanom warunki do przyszłej projekcji i nowego pamiętania tego wydarzenia.

\section{Dekonstrukcja mitu zwycięstwa}

Nieco inny los spotkał trzeci mit fundacyjny Związku Radzieckiego. Fundamenty mitu zwycięstwa zostały naruszone już w ostatnich latach istnienia Związku Radzieckiego. Stawiane przez republiki bałtyckie żądania upublicznienia i potępienia tajnych protokołów do paktu Hitlera ze Stalinem z 1939 roku zakończyły się ich zwycięstwem, mimo wyraźnego sprzeciwu najwyższych organów partyjnych Związku Radzieckiego (Шерлок, 2014, ss. 214-220). Ta niechęć była zrozumiała. Najwyższe władze sowieckie już wówczas przewidywały, że potępienie umowy wywoła pytanie o prawne uwarunkowanie zachodnich granic Związku Radzieckiego. Jak się okazało, miały one słuszność. Wkrótce po potępieniu tajnych protokołów paktu, na podstawie decyzji deputowanych ludowych, kraje bałtyckie ogłosiły niepodległość i wystąpiły ze Związku Radzieckiego. Jednak potępienie tajnych protokołów wpłynęło także na sam mit zwycięstwa w Wielkiej Wojnie Ojczyźnianej: pierwszy raz od zakończenia II wojny światowej w Związku Radzieckim przyznano, że Armia Czerwona była nie tylko wyzwolicielką innych krajów, ale także agresorką. Jeszcze większych wstrząsów mit zwycięstwa doznał jednak w suwerennej Rosji w 1992 roku po opublikowaniu przez Wiktora Suworowa książki Ледокол (Lodołamacz). Społeczeństwo rosyjskie najbardziej zaszokowała teza Suworowa, że wkroczenie Niemiec hitlerowskich na terytorium Związku Radzieckiego 22 czerwca 1941 roku było krokiem prewencyjnym, nieoczekiwanym ciosem zadanym Armii Czerwonej planującej wojnę przeciwko Niemcom (Langenohl, 2000, ss. 166-168). Równolegle do zażartych debat na temat twierdzeń Suworowa ukazało się wiele tekstów wytykających błędy władzy sowieckiej w latach Wielkiej Wojny Ojczyźnianej, które kosztowały życie wielu ludzi i ich niepotrzebną ofiarę. Należy podkreślić, że niezmiennie akcentowany w różnych publikacjach argument niewinnych ofiar był najskuteczniejszą bronią w walce z sowieckim mitem zwycięstwa. W czasie debat narodził się także zupełnie nowy dla rosyjskiego społeczeństwa dyskurs władzy i społeczeństwa. O ile w czasach Związku Radzieckiego, a także dzisiejszej Rosji, stale powtarzano, że władza i państwo są ważniejsze niż społeczeństwo i jednostka, o tyle w debatach na temat Wielkiej Wojny Ojczyźnianej ostro potępiono władzę i państwo sowieckie jako takie, akcentując tragiczne doświadczenia społeczeństwa i jednostki (Langenohl, 2000, ss. 188-208). 
Z perspektywy badań nad kulturą pamięci te dyskusje były ważne chociażby dlatego, że stały się podstawą dla wprowadzenia poprawek do rosyjskich ustaw memorialnych. W 1996 roku w Rosji została przyjęta nowa ustawa, w której 22 czerwca został nazwany Dniem Pamięci i Żałoby (Lutz-Auras, 2013, ss. 269-270). W ten oto sposób w Rosji został utrwalony dyskurs ofiary, a nie zwycięzcy (zwycięstwa).

Tym samym rosyjska kultura pamięci końca XX wieku, w której istotne miejsce zajęła figura ofiary, upodobniła się do kultur pamięci sąsiednich państw Europy Środkowo-Wschodniej. Jednak postawienie między nimi znaku równości nie byłoby do końca zasadne. Po pierwsze dlatego, że pomimo umocnienia w rosyjskim ustawodawstwie znaczenia figury ofiary, w niemałej części Rosji nadal były żywe wyobrażenia na temat dawnego mitu zwycięstwa. Jego zwolennicy także aktywnie uczestniczyli w dyskusjach na temat twierdzeń zawartych w książce Suworowa czy ogólnie na temat oceny Wielkiej Wojny Ojczyźnianej. Należy potwierdzić, że w połowie ostatniego dziesięciolecia XX wieku w Rosji powstały dwie grupy społeczne reprezentujące diametralnie skrajne poglądy na Wielką Wojnę Ojczyźnianą. Jednak dla każdej z nich zagadnieniem największej wagi nie był jedynie sam przedmiot dyskusji. Te dwie grupy społeczne odróżniał także pogląd na komunizm oraz Związek Radziecki. Przedstawiciele obozu liberalnego, burzący sowiecki mit zwycięstwa, byli krytycznie nastawieni do komunistycznej przeszłości i samego komunizmu. Inaczej ich oponenci, którzy bronili tego mitu i dążyli do retrospektywnej legitymizacji Związku Radzieckiego (Langenohl, 2000, s. 306).

\section{Odrodzenie mitu zwycięstwa}

Pierwsze próby rehabilitacji mitu zwycięstwa dało się zauważyć już w roku 1995. Po dłuższej przerwie obchodzono wówczas w Moskwie rocznicę zwycięstwa w Wielkiej Wojnie Ojczyźnianej, podczas której na Placu Czerwonym zorganizowano także pochód weteranów. Składową częścią obchodów była też defilada wojskowa, która jednak nie odbyła się w tradycyjnym miejscu - na Placu Czerwonym, a w sąsiedztwie nowo przygotowanego miejsca pamięci Поклонная Гора (pol. Pokłonna Góra, pot. Pokłonka) (Altrichter, 2004, s. 487). O tym, że to właśnie Jelcyn odnowił mit zwycięstwa w Wielkiej Wojnie Ojczyźnianej zdecydowały okoliczności wewnętrzne, po pierwsze początek wojny w Czeczenii. Choć z drugiej strony, być może dużo ważniejszym czynnikiem niż wojna w Czeczenii były desperackie próby poszukiwania przez nową władzę takich wątków przeszłości, które mogłyby stabilizować sytuację $\mathrm{w}$ rozdartym rosyjskim społeczeństwie.

Po długich i bezowocnych poszukiwaniach, których odzwierciedleniem może być ogłoszony w 1996 roku przez Jelcyna konkurs „Idee dla Rosji” (Becker, 2016, s. 34), powrócono do problematyki Wielkiej Wojny Ojczyźnianej (Lutz-Auras, 2013, 
ss. 133-136). Choć na pierwszy rzut oka mogłoby się wydawać, że powrócono do sowieckiej wersji tego mitu, to jednak pojawiło się w nim kilka istotnych różnic: zwycięstwo w Wielkiej Wojnie Ojczyźnianej było obecnie przypisywane wyłącznie narodowi rosyjskiemu (Исаев, 2015, ss. 401-402), a podczas obchodów rocznicy zwycięstwa akcentowano temat ofiar wojny. Co ważne, odnowiony przez Jelcyna mit zwycięstwa, był wykorzystywany nie jako element konfliktu z Zachodem, a raczej jako element pokoju i zgody. Pamięć zwycięstwa była dla członków koalicji antyhitlerowskiej jednocześnie impulsem do wspólnego pokonywania aktualnych wyzwań wobec Rosji i świata (Малинова, 2015, s. 100).

Kolejny krok, który przywrócił mitowi zwycięstwa centralne miejsce w kulturze pamięci współczesnej Rosji, wykonał następny prezydent Rosji - Władimir Putin. Od pierwszych dni swojej prezydentury akcentował on znaczenie budowy silnego państwa i patriotyzmu. Dobrą okazją do umocnienia toposu patriotyczno-państwowego w rosyjskiej kulturze pamięci były obchody 60. rocznicy zakończenia II wojny światowej i siedemdziesięciolecia jej wybuchu (Sheliha, 2011, ss. 175-198). Właśnie wtedy, a konkretnie w 2005 roku, z inicjatywy Agencji Informacyjnej „Novosti” został także zaprojektowany, bardzo popularny w Rosji i poza jej granicami, specjalny symbol upamiętniający Dzień Zwycięstwa - „wstążka gieorgijewska” (wstążka św. Jerzego) (Миллер, 2012, ss. 164-168). W 2005 roku po wygłoszeniu mowy rehabilitującej Związek Radziecki, przywódca Rosji ostatecznie zerwał z tworzoną przez Borysa Jelcyna tradycją antykomunistyczną. Putin jeszcze raz poddał transformacji także zawartość samego mitu: początkowo podkreślał znaczenie zwycięstwa i akcentował fakt równości Rosji wobec krajów zachodnich, a później - wykorzystał ten wątek jako istotny motyw uprawniający do konfrontacji z Zachodem (Малинова, 2015, ss. 113-114). W 2007 roku, po wprowadzeniu do kalendarza Dnia Bohaterów Ojczyzny (Малинова, 2015, s. 170) rozszerzyły się także możliwości dodatkowej aktualizacji tematu Wielkiej Wojny Ojczyźnianej. Transformowany w ten sposób mit podczas drugiej kadencji prezydenta Putina ostatecznie stał się ważną częścią kultury pamięci Rosji, aktywnie chronioną także przez politykę historyczną rosyjskiego państwa.

\section{Proces powstawania najważniejszych kierunków polityki historycznej państwa rosyjskiego}

W pracach rosyjskich badaczy często się podkreśla, że współczesne państwo rosyjskie zaczęło realizować aktywną politykę historyczną o wiele później niż jego sąsiedzi. Znany na Zachodzie historyk Aleksiej Miller twierdzi, że władze Rosji zaczęły się interesować kwestiami przeszłości dopiero po roku 2000. To prawda, analiza sytuacji Rosji od powstania współczesnego państwa w roku 1992 aż do 2000, wyraźnie wskazuje, że jej aktywność w dziedzinie badania własnej przeszłości była minimalna. Pewne 
kroki podejmowano w celu rehabilitacji przeszłości carskiej, więcej praw przywrócono Kościołowi prawosławnemu. Jednak były to raczej niezbędne działania w procesie tworzenia państwa niźli konsekwentna polityka historyczna. W okresie 1992-2000 wprowadzono tylko jeden zakaz: w 1997 roku z obiegu wycofano podręcznik A. Kredera, w którym winą za wybuch II wojny światowej obciąża się zarówno hitlerowskie Niemcy, jak i stalinowski Związek Radziecki. Jednak ten zakaz nie zmienił liberalnej polityki wydawania podręczników aż do 2004 roku, kiedy Ministerstwo Oświaty Rosji wprowadziło praktykę zatwierdzania listy podręczników wykorzystywanych w rosyjskich szkołach (Гузенкова, 2015, ss. 30-31). Oczywiste jest, że jedną z przyczyn takiej dość słabej polityki historycznej prowadzonej przez państwo rosyjskie był adekwatnie niski autorytet państwa rosyjskiego, a także ambiwalentny stosunek warstw rządzących do przeszłości. Pozwolił on rosyjskim komunistom i nacjonalistom na formowanie alternatywnej polityki historycznej. W tym czasie w środowisku Igora Frojanowa, Aleksandra Panarina i Aleksandra Dugina została sformułowana teoria o cywilizacji słowiańsko-prawosławnej. W tym okresie ikoną rosyjskich nacjonalistów został Lew Gumilow. Na podstawie jego dorobku ponownie zinterpretowano okres sowiecki, usuwając z niego to, co wiązało się z komunizmem. W nowej interpretacji system sowiecki jest traktowany jako epoka, w której najlepiej rozwinęły się cechy narodu rosyjskiego: narodowe, wspólnotowe (sobornost'), państwowe. Choć były one popularne w Rosji w ostatnim dziesięcioleciu XX wieku, to jednak nie można twierdzić, że panował w stosunku do nich społeczny konsensus (Копосов, 2011, ss. 129-130). Dokonało się to później, podczas prezydentury Władimira Putina.

\section{Transformacje rosyjskiej polityki historycznej: problem podręczników do historii}

Kształtująca się polityka historyczna państwa rosyjskiego, doświadczyła po 2000 roku wielu przemian. Najpierw jej działania zostały wymierzone przeciwko rosyjskim historykom i intelektualistom. Prezydent Rosji w 2003 roku podczas spotkania z rosyjskimi historykami wyraźnie podkreślił, że Rosja potrzebuje podręcznika historii, który będzie rozwijał w uczniach poczucie dumy z Ojczyzny, i skrytykował tych autorów, którzy wiele uwagi poświęcają negatywnemu przekazowi historii Rosji (Becker, 2016, ss. 47-49). Na konkretne kroki w zakresie nowej polityki nie trzeba było długo czekać. Już w 2003 roku za niepożądany w rosyjskich szkołach został uznany podręcznik Igora Doluckiego, z którego system oświaty korzystał od 1993 roku. Jednym z głównych powodów, dla którego autor popadł w niełaskę polityków była zamieszczona w podręczniku ocena Wielkiej Wojny Ojczyźnianej. Zdanie autora na temat początku wojny niewiele się różniło od uznanego już wcześniej za niepożądany, podręcznika A. Kredera. Obaj autorzy rozpoczynali swoją narrację o Wielkiej Wojnie 
Ojczyźnianej od 1939 roku, a nie - jak było przyjęte w Rosji - od roku 1941. Jednak jeszcze większe niezadowolenie mogły wzbudzić wnioski Doluckiego, oceniające zwycięstwo Związku Radzieckiego nad hitlerowskimi Niemcami. Zdaniem autora książki, zwycięstwo nie dało rosyjskiemu społeczeństwu nic ponad umocnieniem systemu stalinowskiego (Ожиганова, Кузнечевский, \& Филянова, 2012, s. 30). Ро kilku miesiącach od spotkania Putina $\mathrm{z}$ historykami rosyjskimi, ówczesny minister oświaty Rosji wydał zarządzenie nakazujące kontrolę wszystkich podręczników do nauczania historii i zwrócenie szczególnej uwagi na przesadny pluralizm. W 2004 roku $\mathrm{w}$ celu realizacji powyższego ministerialnego zarządzenia opracowano regulamin wykorzystywania podręczników w szkołach. Od tej chwili podręczniki musiały uzyskać aprobatę rosyjskiego ministerstwa oświaty.

Wart podkreślenia jest jeszcze jeden wymóg wobec autorów podręczników, które od 2003 roku musiały zawierać praktyczne ćwiczenia odwołujące się do pamięci zbiorowej. W przygotowywanych po 2003 roku podręcznikach jednym z najpopularniejszych zadań było to zachęcające uczniów do przeprowadzenia wywiadów z rodzicami na temat udziału krewnych w Wielkiej Wojnie Ojczyźnianej. W ten sposób szkoła $\mathrm{w}$ istotny sposób przyczyniła się do wzmocnienia generacyjnych więzi rosyjskich uczniów i ich rodzin z tym wydarzeniem (Копосов, 2011, ss. 159, 163-164). Nie ograniczono się jednak tylko do takich środków. Podczas gdy prezydent Rosji ponawiał żądania dotyczące ujednolicenia podręczników do nauczania historii, w 2007 roku ukazał się podręcznik Filipowa i Danilowa uważany za potencjalnie podstawowy podręcznik dla wszystkich szkół w Rosji (Миллер, 2015, ss. 212-214). I chociaż nie stał się głównym podręcznikiem w rosyjskich szkołach, to jednak protekcja Putina wyraźnie pomogła autorom (Becker, 2016, s. 51).

Kolejne zmiany w dziedzinie podręczników do nauczania historii przyniosła także powołana w 2009 roku przez prezydenta Miedwiediewa Komisja ds. Przeciwdziałania Fałszowaniu Historii. Na swoich posiedzeniach komisja rekomendowała ministerstwu oświaty powtórną kontrolę podręczników, jednak tym razem pod kątem obecności w nich tekstów pomniejszających znaczenie Rosji w historii światowej. Pod wpływem działań komisji Ministerstwo Oświaty Rosji w 2012 roku rozpoczęło przygotowanie nowego podręcznika historii dla nauczycieli pt. Dyskusyjne problemy historii Rosji; dla nich został także przygotowany podręcznik pod wymownym tytułem Fałszowanie historii narodowej (Becker, 2016, ss. 95, 99).

W analizowanym okresie do spraw podręczników ostatni raz powrócono w 2013 roku. Jeszcze raz z pełną mocą powróciła sprawa jednego wspólnego podręcznika historii i ponownie jej inicjatorem był prezydent Putin. Przygotowanie koncepcji takiego podręcznika zlecono Instytutowi Historii Powszechnej Rosyjskiej Akademii Nauk, który już w połowie następnego roku wykonał zadanie i zaprezentował swoją ideę. Podczas burzliwych dyskusji zrezygnowano z pomysłu jednego podręcznika, zdecydowano jednak, że wszystkie podręczniki muszą spełniać ogólne założenia 
zaprezentowanej koncepcji (Миллер, 2015, ss. 220-225). Jest oczywiste, że polityka oświatowa, a szczególnie programy nauczania historii, jeszcze długo pozostaną jednym z najważniejszych obiektów polityki historycznej Rosji.

\section{Przemiany polityki historycznej Rosji po roku 2005}

Sprawa podręczników historii miała nieco szerszy kontekst, niż to się mogło wydawać na pierwszy rzut oka. Wymogi stawiane autorom podręczników, co do właściwego ukazania danego problemu z przeszłości, stały się drogowskazem dla wszystkich zajmujących się przeszłością. To jednak nie wystarczyło władzom Rosji. Początek XXI wieku przyniósł nowe wyzwania w kwestii wzmocnienia autorytetu rosyjskiej historii oraz stosunku do przeszłości Rosji i Związku Radzieckiego, także na arenie międzynarodowej.

Dlatego w następnym okresie kontynuowano surową politykę kontroli podręczników historii, rozpoczęto także aktywne działania w sferze polityki zagranicznej. Państwo rosyjskie wkroczyło w następny etap polityki historycznej lepiej przygotowane. W pierwszej kolejności stworzono nowe instrumenty realizacji polityki historycznej. Rosja nie poszła w ślady inny krajów postkomunistycznych i nie utworzyła Instytutu Pamięci Narodowej, jak to proponowali niektórzy eksperci jeszcze w 2003 roku, ale wybrała nieco trudniejszą i prawdopodobnie efektywniejszą drogę.

Zamiast jednej instytucji powołano wiele organizacji, które nie były elementami państwowych struktur, a jednak otrzymywały finansowanie oraz wsparcie logistyczne ze strony państwa. W celu realizacji celów rosyjskiej polityki historycznej założono wydawnictwo „Europa”, w 2006 roku agencję informacyjną REGNUM, w 2008 roku fundację „Pamięć Historyczna” (Колеров, 2014, ss. 469-473), fundację „Perspektywa Historyczna" (2004) oraz wiele różnorodnych portali internetowych (Becker, 2016, ss. 73-75).

Rok 2005 był przełomowy w procesie formowania aktywnej polityki historycznej Rosji wobec krajów sąsiednich. Od tego momentu celem rosyjskiej polityki historycznej stali się nie tylko odmiennie myślący mieszkańcy Rosji, ale także obce państwa. Właśnie wtedy Rosja zorganizowała ogromne uroczystości, na które zostali zaproszeni przywódcy wielu krajów świata. Obchody 9 Maja w Moskwie miały pokazać całemu światu i własnemu społeczeństwu, że Rosja jest szanowanym na całym świecie mocarstwem. Odmowa prezydentów Estonii, Litwy i Ukrainy udziału w uroczystościach została potraktowana przez Władimira Putina jako osobista obraza i zniewaga rosyjskiego państwa. Po dwóch latach, gdy w 2007 roku Estonia przeniosła wykonany z brązu pomnik żołnierza radzieckiego (Brügemann, 2008, ss. 129-146), w Rosji podjęto decyzję o wszczęciu aktywnych działań w zakresie polityki historycznej także przeciwko osobom i organizacjom zagranicznym. 
Jeśli chodzi o politykę przeszłości, to koniec zimnej wojny oznaczał także koniec dwóch dominujących narracji o zakończeniu II wojny światowej. Podczas zimnej wojny narracja zachodnia i sowiecka były dość podobne. Teraz jednak pojawiła się trzecia narracja - wschodnio-środkowo-europejska, a nawet czwarta - niemiecka. Próba osiągnięcia uznania narracji rosyjskiej na forum międzynarodowym i towarzyszący temu opór, przede wszystkim ze strony krajów bałtyckich i Polski, miał ogromny wpływ na nowe zjawisko: wojny pamięci w regionie. Inne spojrzenie na rolę Armii Czerwonej w Polsce i krajach bałtyckich, negujące wagę zwycięstwa nad nazizmem oraz mit Armii Radzieckiej jako wyzwolicielki Europy (Торбаков, 2013, ss. 103-106), niszczył i niszczy dwa podstawowe filary rosyjskiej polityki pamięci.

Właśnie dlatego w 2009 roku zarządzeniem prezydenta Dmitrija Miedwiediewa powołano Komisję ds. Przeciwdziałania Fałszowaniu Historii (Michaleva, 2009, ss. 56-57; Russland kämpft: Gesetz und Kommission gegen Geschichtsfälscher Russland, 2009, ss. 7-8). Jej stworzenie było zarazem odpowiedzią na przyjętą w tym samym roku w Wilnie rezolucję Zgromadzenia Parlamentarnego OBWE, potępiającą nazizm i stalinizm (Малинова, 2015, s. 122).

W 2012 roku komisja została rozwiązana. W przeciwieństwie do zarządzenia o jej powołaniu, jej likwidacja przeszła niemal niezauważona przez środki masowego przekazu. Bezpośrednie oceny działalności komisji znalazły odzwierciedlenie w krytycznych opiniach badaczy; jednak miała ona spory oddźwięk poza głównym nurtem swoich działań. Choć sama komisja niewiele osiągnęła, to jednak dzięki współpracy z instytucjami powołanymi do prowadzenia rosyjskiej polityki historycznej w 2009 roku zainicjowała publikację dwóch zbiorów źródeł, których celem było naświetlenie polityki zagranicznej Polski i krajów bałtyckich wobec kwestii II wojny światowej (Соцков, 2009a, 2009b). W tym samym roku fundacje: „Perspektywa Historyczna” oraz „Pamięć Historyczna”, kontynuowały tematykę polską, wydając zbiór dokumentów o wymownym tytule Партитура Второй мировой: Кто и когда начал войну? (Partytura drugiej wojny światowej. Kto i kiedy rozpoczął wojnę?) (Нарочницкая, 2009). Odpowiedź na tak postawione pytanie brzmiała nieco paradoksalnie. Zdaniem autorów tego zbioru Polska jest współodpowiedzialna za wybuch II wojny światowej. Oskarżenia wobec Polski w 2009 roku zostały znów powtórzone w artykule opublikowanym na stronie internetowej Ministerstwa Obrony Rosji (Biuro Bezpieczeństwa Narodowego, 2009), co tylko jeszcze raz potwierdziło ścisłe związki wymienionych wyżej organizacji pozarządowych z Kremlem.

Innym tematem, który chętnie podejmują realizatorzy rosyjskiej polityki historycznej, jest problematyka udziału obywateli sąsiedzkich państw w Holocauście. Biorąc pod uwagę jednolite stanowisko Unii Europejskiej wobec Holocaustu, dążą oni do wzbudzenia w krajach „starej Unii” niezadowolenia z nowych członków $\mathrm{z}$ bloku postsowieckiego i postkomunistycznego. Mimo prowadzenia przez Rosję agresywnej polityki historycznej, wielu Rosjanom wydaje się, że to właśnie ich ojczy- 
zna zmuszona jest do obrony przed atakami innych krajów. Chyba najradykalniej na ten temat wypowiedziała się zastępczyni dyrektora Instytutu Badań Strategicznych Rosji - Tamara Guzenkowa, która określiła próby dekonstrukcji mitu zwycięstwa jako globalny projekt skierowany przeciwko Rosji, w którym udział bierze nawet Hollywood (Гузенкова, 2015, ss. 35-37).

Aneksja Krymu, wkroczenie Rosji na wschodnią Ukrainę wyraźnie ukazało agresywniejszą stronę mitu zwycięstwa. Choć oficjalnie Rosja zaprzecza swemu udziałowi w działaniach wojennych, to jednak cały konflikt przedstawia jako walkę sił dobra ze złem, przeciwstawianie się faszystom, banderowcom itp. Choć wojskowa inwazja na Ukrainę została przyjęta w Rosji entuzjastycznie, to jednak struktury władzy wykorzystały tę sytuację także do zaostrzenia kursu polityki historycznej. W maju 2014 roku rosyjska Duma Państwowa przyjęła ustawę przewidującą odpowiedzialność karną za rehabilitowanie działań nazistowskich. Jak wiadomo, projekt tej ustawy był dyskutowany jeszcze w 2009 roku, jednak wówczas na drodze do jej przyjęcia stanęła powołana przez prezydenta Dmitrija Miedwiediewa Komisja ds. Przeciwdziałania Fałszowaniu Historii.

W nowo przyjętej ustawie przewidziano odpowiedzialność karną za:

a) negowanie faktów, które zostały udowodnione przez Trybunał Wojskowy w Norymberdze,

b) usprawiedliwianie wymienionych w wyroku zbrodni,

c) popularyzację $\mathrm{w}$ mediach fałszywych informacji o działaniach Związku Radzieckiego podczas II wojny światowej,

d) prowadzenie wyżej wymienionych działań przez podejrzanych, którzy wykorzystują do tego swoją pozycję służbową lub upowszechniają informacje przez społecznościowe kanały informacyjne (co zostało zagrożone jeszcze wyższą karą),

e) publiczne okazywanie pogardy wobec dni pamięci związanych z Wielką Wojną Ojczyźnianą,

f) hańbienie symboli i pomników związanych z wojenną chwałą Rosji (Гузенкова, 2015, ss. 124-125).

Jednymi z pierwszych, którzy stali się ofiarami nowej ustawy, byli profesorowie Instytutu Stosunków Międzynarodowych w Moskwie. Zostali oni zwolnieni z pracy za publiczne porównanie aneksji Krymu z anschlussem Austrii w 1938 roku (Миллер, 2015, ss. 226-230). W roku 2014 przemiany dotknęły także Centrum Upamiętnienia Historii Represji Politycznych „Perm-36”, jedną z najbardziej znanych instytucji w Rosji i na świecie. Centrum powstało w 1996 roku na terenie dawnego obozu pracy przymusowej GUŁAG (1942-1988). Za swoją aktywną działalność edukacyjną zdobyło uznanie nie tylko za granicą, ale także w samej Rosji. Centrum zostało zreorganizowane w sposób zmieniający istotę jego działalności (Гизен, 2015, ss. 363-373).

Nowa ustawa dała Rosji bezprecedensową możliwość ingerowania w sprawy wewnętrzne innych krajów. Po raz pierwszy skorzystano z niej w 2015 roku także 
w stosunku do cudzoziemców, gdy ukraińskim żołnierzom wytoczono sprawę karną o niszczenie sowieckich pomników na terytorium Ukrainy (Мальцев, Усова, Сошин, \& Атаев, 2015, s. 47). Szeroka formuła ustawy stwarza duże pole do jej wykorzystywania i realna wydaje się możliwość, że to nie będą jedyne ofiary najnowszej rosyjskiej ustawy memorialnej.

\section{Inne tematy historyczne w kulturze pamięci Rosji}

W typologicznym ujęciu kultur pamięci, Rosja należy do grupy krajów o modelu kultury pamięci opierającym się na „krótkiej pamięci”, tzn. którego społeczeństwo buduje swą tożsamość wyłącznie na przeszłości związanej z wydarzeniami XX wieku. Należy zauważyć, że zawężenie zasobów pamięci do konkretnych tematów najnowszej historii wiąże się z istotnymi przełomami historycznymi, które w znaczący sposób zmieniły rozwój historii w konkretnym kraju. W Rosji takim wydarzeniem była niewątpliwie rewolucja październikowa (przewrót) 1917 roku. Daje się zauważyć, że prawdopodobnie najlepszym lekarstwem na takie społeczne traumy są nowe transformacje, jak na przykład ostateczny rozpad Związku Radzieckiego w roku 1991. Badacze kultury pamięci zauważają, że dla uwiarygodnienia nowego zjawiska ważna jest nie tylko przeszłość formująca przewodnią narrację historyczną (w Rosji to mit zwycięstwa w Wielkiej Wojnie Ojczyźnianej), ale także jego geneza (J. Assmann, 2000). W sowieckiej kulturze pamięci tę funkcję pełnił mit rewolucji październikowej, naturalne więc jest pytanie o to, jak zagadnienie początków Rosji jest traktowane we współczesnym państwie?

Dodatkowo jeszcze jedna ważna okoliczność zachęca do zwrócenia uwagi na wydarzenia wcześniejszej epoki i możliwości ich wykorzystania w kulturze pamięci Rosji. W teoretycznych rozważaniach o państwach postsowieckich i postkomunistycznych stwierdza się, że powstałe po rozpadzie Związku Radzieckiego państwa oraz te, które odzyskały pełną suwerenność, swój dalszy rozwój związały z okresem przedsowieckim. To zjawisko jest określane w literaturze naukowej jako teoria "powrotu do normalności” (Niedermüller, 2004, ss. 23-24). W praktyce wyglądało to tak, że do nowo konstruowanej kultury pamięci włączano elementy przedsowieckiej kultury pamięci, a nawet na krótko ją rewitalizowano. W tym kontekście naturalne wydaje się być pytanie o zastosowanie tej teorii także do analizy kultury pamięci Rosji. 


\section{Kwestia genezy państwa rosyjskiego we współczesnym społeczeństwie rosyjskim}

Na wstępie należy zaznaczyć, że trudności ze znalezieniem źródeł państwa rosyjskiego pojawiły się już po roku 1991, po powstaniu nie tylko samodzielnej Rosji, ale także Ukrainy. Do tego momentu mówienie o źródłach państwa rosyjskiego tradycyjnie, choć być może nie do końca zasadnie (Korpela, 2008, ss. 127-143), wiązało się z przywołaniem Rusi Kijowskiej. Jak wiadomo po 1991 roku Kijów stał się stolicą innego niepodległego państwa - Ukrainy.

Nowe elementy kultury pamięci nie pojawiają się w próżni, często zaś ich początki są efektem pracy naukowej historyków. Tak się stało chociażby z kwestią źródeł państwowości Rosji. To właśnie w głowach rosyjskich historyków narodziła się teoria o Rusi Kijowskiej jako państwie policentrycznym, którego jednym z najważniejszych centrów obok Kijowa była Stara Ładoga. Prace rosyjskich historyków przyciągnęły uwagę najważniejszych polityków dopiero po roku 2000, jednak Stara Ładoga nie od razu znalazła się w kręgu ich zainteresowań.

W 2001 roku nowy prezydent Rosji - Władimir Putin gościł w Nowogrodzie. Na zaproszenie gubernatora obwodu prezydent odwiedził także stary Nowogród Wielki, który został mu przedstawiony jako prawdziwa kolebka dziejów Rosji. Ta kwestia wyraźnie zainteresowała W. Putina, który podczas spotkania z historykami i archeologami zapytał o znaczenie Kijowa w historii Rosji, a także poprosił o radę, gdzie teraz, gdy Kijów stał się stolicą Ukrainy, należałoby szukać źródeł historii dzisiejszej Rosji. Podczas spotkania dyskutowano o roli Nowogrodu Wielkiego, jednak historycy rosyjscy sceptycznie oceniali możliwości wykorzystania tego tematu w tworzeniu idei narodowej (Шнирельман, 2011, ss. 377-378). Prawdopodobnie właśnie wizyta w Nowogrodzie zainspirowała W. Putina, by interesować się źródłami państwowości rosyjskiej. To wówczas jego uwaga skierowała się na Starą Ładogę. W 2002 roku prezydent Rosji podpisał rozporządzenie w sprawie zaplanowanych na rok 2003 obchodów jubileuszu 1250-lecia Starej Ładogi jako dawnej stolicy Rosji. W jubileuszu wziął udział także W. Putin. W swoim przemówieniu akcentował wagę pamięci historycznej, której niedocenianie stwarza Rosji wiele problemów, nie pozwalając na formułowanie scenariuszy jej przyszłego rozwoju. Wyglądało na to, że działanie Putina na jakiś czas rozwiązało dylemat początków rosyjskiej państwowości.

Jednakże Stara Ładoga mogła się cieszyć zainteresowaniem polityków jedynie przez krótki czas. Na przeszkodzie, by ten archeologiczny zabytek został symbolem państwa rosyjskiego, stanęło skandynawskie pochodzenie pierwszych Rurykowiczów. W zmianie historycznych faktów nie pomogły nawet największe autorytety rosyjskiej nauki, w tym starania Aleksandra Sacharowa, dyrektora Instytutu Historii Rosji Rosyjskiej Akademii Nauk. Jego próby udowodnienia słowiańskiego pochodzenia dynastii Rurykowiczów, nie przekonały politycznych władz Rosji. Ostatni raz w kwestii 
początków Rosji Putin wypowiedział się w 2014 roku natychmiast po aneksji Krymu, podkreślając znaczenie miejscowości Chersoń, miejsca chrztu św. Włodzimierza wielkiego księcia kijowskiego, w historii Rosji (Putin, 2014). Można tylko zgadywać, czy po takim oświadczeniu rosyjskie elity polityczne Rosji już odnalazły początek swojej państwowości i miejsce ucieleśniające ideę narodową, czy też poszukiwania będą kontynuowane.

Należy zwrócić uwagę, że rosyjscy naukowcy podpowiadają, jak można wykorzystać także inne epoki historyczne jako potencjalnie istotne dla kultury pamięci Rosji. Udowadniają tym samym, że w ostatnich latach więcej uwagi poświęca się czasom dawniejszym, dążąc do wykorzystania ukrytych w nich zasobów patriotycznych (Гузенкова, 2015, s. 31). Jak ważna jest cała przeszłość historyczna i jak ją wykorzystać, w jednym ze swych przemówień podkreślał w 2000 roku także prezydent Rosji Władimir Putin. Jego słowa pozwoliły badaczom rosyjskim na sformułowanie tezy o totalnym przejmowaniu przeszłości (Малинова, 2015, ss. 69-70). Jednak te deklaracje nie dały odpowiedzi na pytanie, czy po roku 1991 Rosja związała swój dalszy rozwój i kulturę pamięci z przeszłością przedrewolucyjną i jak owo konstruowanie pamięci wygląda naprawdę.

W tym miejscu należy podkreślić, że wśród poglądów na temat omawianego zagadnienia dość wyraźnie odróżniają się opinie zachodnioeuropejskich i liberalnych rosyjskich badaczy kultury pamięci i polityki. Na Zachodzie panuje tendencja, by uważać, że we współczesnym społeczeństwie rosyjskim obok mitu zwycięstwa ważne miejsce zajmuje tradycja historyczna carskiej Rosji, ze szczególnym uwzględnieniem znaczenia dynastii Romanowów, $w$ tym ostatniego cara zamordowanego przez bolszewików. Głównie autorzy niemieccy uważają, że po rozpadzie Związku Radzieckiego także Rosjanie dążyli do uwzględnienia w swoim dalszym rozwoju historii, którą odkryli w carskiej Rosji (Scherrer, 2009, s. 34). Ważne znaczenie w aktualizowaniu przedrewolucyjnej przeszłości odegrały zorganizowane w 1997 i 2003 roku jubileusze Moskwy i Petersburga. Właśnie wtedy, jak nigdy wcześniej, akcentowano znaczenie dziejów carskiej Rosji. W 1998 roku państwo rosyjskie zorganizowało uroczystość ponownego pochówku zamordowanego przez bolszewików cara Mikołaja II i jego krewnych, a w 2000 roku Rosyjska Cerkiew Prawosławna ogłosiła ich męczennikami systemu sowieckiego (Keghel, 2006, ss. 247-248). Zdaniem niemieckich autorów tradycja carska ostatecznie ugruntowała się we współczesnej Rosji w 2004 roku wraz z wprowadzeniem nowego święta państwowego - Dnia Jedności Narodowej (Keghel, 2009, ss. 119-140).

Z takim stanowiskiem kategorycznie nie zgadzają się badacze rosyjscy. Uznają wprawdzie przedstawione wyżej fakty, ale równocześnie podkreślają, że dla rosyjskich elit politycznych ważniejsze od tradycji carskiej Rosji było odnowienie tradycji prawosławnej. W 2009 roku w Gdańsku podczas sympozjum związanego z obchodami 79. rocznicy wybuchu II wojny światowej z tą opinią zgodził się znany rosyjski 
historyk - Jurij Afanasjew, który scharakteryzował współczesne państwo rosyjskie jako czekistowskie państwo prawosławne (Czauderna, 2009).

Takie głosy rosyjskich badaczy są przekonujące, szczególnie w kontekście jak dotąd ambiwalentnych poglądów współczesnego społeczeństwa rosyjskiego na rewolucję październikową i na Lenina. Autorytarny reżim carskiej Rosji przysparzał wielu problemów twórcom współczesnej Rosji, dążącym do zbudowania państwa demokratycznego. Dlatego najważniejsze osoby w Rosji wypowiadały się na temat tej epoki dwuznacznie. W 1993 roku Borys Jelcyn zachęcał Rosjan do zwrócenia się ku tradycjom demokratycznym Rosji przedrewolucyjnej, a w 1996 roku oznajmił, że to właśnie brak demokratycznych instytucji w carskiej Rosji doprowadził kraj do katastrofy rewolucji październikowej (Малинова, 2015, ss. 42, 43).

Częściowo poglądy badaczy rosyjskich potwierdziły obchody jubileuszu 400-lecia dynastii Romanowów w 2013 roku. Podczas uroczystości jubileuszowych wyraźnie unikano nazwania po imieniu zabójców ostatnich przedstawicieli dynastii Romanowów, podkreślano natomiast znaczenie prawosławia dla rosyjskiego społeczeństwa (Лапин, 2016, ss. 7-22). Rosyjscy naukowcy przyznają wprost, że - poza Białorusią Rosja jest prawdopodobnie jedynym krajem postkomunistycznym, który nie próbował ostatecznie zerwać $\mathrm{z}$ komunizmem, a nawet świadomie podkreślił kontynuację tradycji Związku Radzieckiego (Торбаков, 2013, s. 116). Daje to podstawy do wyciągnięcia konkretnych wniosków na temat odrębności kultury pamięci Rosji: dzisiejsza Rosja pozostaje jedynym krajem postkomunistycznym i postsowieckim, w stosunku do którego nie da się zastosować teorii „powrotu do normalności”. Wcześniej opisano, jakim zmianom ulegało pojęcie Związku Radzieckiego we współczesnej Rosji. W ten sposób kontynuacja przetransformowanych w XXI wieku treści tradycji radzieckich, pozwoliła rosyjskim elitom politycznym rozwinąć nową narrację historyczną. Nie tylko nie podejmowała ona żadnej konfrontacji z mitem zwycięstwa, ale nawet uczyniła z niego swoją oś centralną - to opowieść o imperium, które także w potocznym języku pojawia się jako silne suwerenne państwo. W tym miejscu należy wyraźnie podkreślić fakt, że to właśnie silne państwo (dieržava), a nie mit zwycięstwa, stoi w centrum rosyjskiej kultury pamięci.

\section{Czy istnieje alternatywa dla rosyjskiej dominującej narracji pamięci? O styku stalinizmu i antystalinizmu w dzisiejszej Rosji}

Przedstawiona wyżej analiza w pewnym sensie jest zaprzeczeniem tak sformułowanego pytania. Jednak szerszy ogląd sytuacji Rosji pozwala na choćby teoretyczne rozważenie możliwości istnienia alternatywy dla dominującej narracji. Pierwszą przesłanką dla takich rozważań jest sposób formowania kultury pamięci w Rosji. W istocie jest on narzucony przez elity polityczne i nie podlega żadnej dyskusji społecznej. 
Regułą jest, że podczas zmian politycznej koniunktury najłatwiej naruszyć takie właśnie konstrukty kultury pamięci. Wydawało się, że w ostatnich dziesięcioleciach XX wieku po państwowej kampanii usuwania „białych plam” i przeprowadzeniu procesów destalinizacyjnych, społeczeństwo rosyjskie uwolniło się od syndromu Stalina. Jednak wydarzenia z początku XXI wieku wyraźnie pokazały, że tak nie jest. Szeregi sympatyków Stalina w Rosji znów urosły, jednak obecnie, przeciwwagą dla stałej dominacji zwolenników stalinizmu pozostaje ruch antystalinowski. Rozwój sytuacji w latach 2009-2013 udowodnił, że opozycja antystalinowska wcale nie jest już taka słaba. Nowe stanowisko Rosji zapoczątkowała wizyta W. Putina w Gdańsku 1 września 2009 roku, podczas której krytycznie wypowiedział się na temat paktu Hitler-Stalin i wymienił Katyń jako zbrodnię Stalina. Miesiąc później jeszcze bardziej krytyczną pozycję wobec Stalina zajął ówczesny prezydent Rosji Dmitrij Miedwiediew. Podkreślił, że pamięć ofiar terroru jest nie mniej ważna niż pamięć bohaterów wojennych, zarazem dodając, że utworzona przez niego Komisja ds. Przeciwdziałania Fałszowaniu Historii powinna zająć się także tymi, którzy próbują usprawiedliwiać zabójców przedstawicieli narodu rosyjskiego.

Siedemdziesiąta rocznica zbrodni katyńskiej oraz katastrofa smoleńska jeszcze bardziej wzmocniły antystalinowską postawę zarówno prezydenta Rosji, jak i przywódcy rządu. Ważna była nie tylko antystalinowska retoryka najważniejszych osób w Rosji, ale także konkretne projekty. Na początku 2011 roku działająca przy prezydencie Rosji Komisja Społeczeństwa Obywatelskiego i Praw Człowieka przygotowała program „Upamiętnienia ofiar reżimu totalitarnego”. W tym samym roku program uzyskał akceptację prezydenta Miedwiediewa, a pod koniec roku utworzono grupę roboczą do realizacji określonych w programie zadań. Zmiana na stanowisku prezydenta Rosji w 2013 roku nie wpłynęła na poglądy władzy w tej kwestii. Na polecenie W. Putina program miał być ostatecznie przygotowany do społecznej dyskusji do końca roku, później miały być realizowane konkretne zaplanowane w programie zadania.

W latach 2011-2013 kształt dyskutowanemu programowi nadała konsekwentnie walcząca ze stalinizmem organizacja „Memoriał”. Program przewidywał budowę centralnych miejsc upamiętnień ofiar stalinowskich (pomników i muzeów) stworzenie jednolitego banku danych o ofiarach, polepszenie sytuacji materialnej osób, które ucierpiały w czasach stalinowskich, a także dalszą prawną rehabilitację ofiar stalinizmu. Ponadto w projekcie znalazła się ocena działalności osób odpowiedzialnych za zbrodnie oraz propozycja szerokiej działalności edukacyjnej.

Wojna na Ukrainie istotnie zmieniła także sytuację w samej Rosji, jednak przygotowywanego programu nie porzucono, o czym świadczy otwarta w 2015 roku w Moskwie, w nowym budynku, nowa ekspozycja w Muzeum Historii Gułagu (W Moskwie otworzono Muzeum Historii Gułagu, 2015). Niewątpliwie także w przyszłości w Rosji może mieć miejsce jeszcze niejedna konfrontacja dwóch różnych modeli kultur pamięci. 


\section{Zamiast wniosków}

Na wyciągnięcie wniosków i uogólnienia na temat kultury pamięci i polityki historycznej Rosji, gdy jeszcze trwa analiza sytuacji w innych krajach, jest dziś jeszcze za wcześnie. Można jedynie podzielić się kilkoma uwagami na ten temat.

Przeprowadzona analiza ukazuje, że przypadek Rosji wyraźnie przeczy poglądom tych teoretyków, którzy negują możliwość istnienia narodowej kultury pamięci. Po skomplikowanym etapie transformacji postsowieckiej w Rosji kultura pamięci w 2005 roku nabrała konkretnych kształtów. W jej centrum znalazła się opowieść o imperium (dieržava), którego status powinna uznać także reszta świata. Podstawowym symbolicznym zasobem dla toposu silnego państwa rosyjskiego jest mit zwycięstwa w Wielkiej Wojnie Ojczyźnianej. Jednak w ostatnim czasie do wzmocnienia mitu centralnego aktywnie wykorzystuje się także selektywnie wybrane fakty z innych epok historycznych.

Symboliczne figury tworzącej się czy też już ukształtowanej kultury pamięci są w Rosji stale reinterpretowane. Także mit zwycięstwa po 1992 roku przeszedł kilka etapów transformacji: $w$ pierwszych latach prezydentury Borysa Jelcyna (do roku 1995) dominowały aktywne próby dekonstrukcji tego mitu, w latach 1995-2000 był on odnowiony, akcentowano przede wszystkim status rosyjskiego narodu jako niepokonanej ofiary. W latach 2000-2005 w centrum mitu znów usytuowano państwo, a w ostatnim czasie został on poddany instrumentalizacji i wykorzystany jako argument w konfrontacji Rosji z Zachodem. Po 2011 roku wyraźnie widać próby ilościowego rozszerzenia zasobu instrumentarium symbolicznego za pomocą aktywnego wykorzystania wybranych faktów z innych epok historycznych.

Choć w Rosji wyraźnie dominuje meganarracja imperialna (dieržava), to jednak ma ona swoją konkurencję. W Rosji nadal w silnej opozycji do mitu zwycięstwa pozostaje mit ofiary. Lata 2009-2013 wyraźnie pokazały żywotność pamięci o ofiarach stalinowskich. W tym sensie struktura pamięci Rosji, choć z pewnymi wyjątkami, może być porównywana do polskiej, jednocześnie różniąc się istotnie od niemieckiej, litewskiej czy białoruskiej. W tych krajach wyraźnie wyrażona jest jedna kultura pamięci, choć jej treść zawiera różne wątki tematyczne. W kontekście regionalnym nie mieści się Ukraina, w której jednolita polityka pamięci jest wprawdzie formowana, ale to dopiero początek procesu.

Tłum. Małgorzata Kasner

\section{Bibliografia}

Altrichter, H. (2004). „Der Große Vaterländische Krieg“: Zur Entstehung und Entsakralisierung eines Mythos. W H. Altrichter, K. Herbers, \& H. Neuhaus (Red.), Mythen in der Geschichte (ss. 471-494). Freiburg am Breisgau: Rombach. 
Assmann, A., \& Shortt, L. (2012). Memory and political change. Basingstoke: Palgrave Macmillan UK. https://doi.org/10.1057/9780230354241

Assmann, J. (2000). Das kulturelle Gedächtnis: Schrift, Erinnerung und politische Identität in frühen Hochkulturen (3. wyd.). München: Beck.

Becker, A. (2016). Mythos Stalin: Stalinismus und staatliche Geschichtspolitik im postsowjetischen Russland der Ära Putin. Berlin: Be.bra Wissenschaft Verlag.

Biuro Bezpieczeństwa Narodowego. (2009, wrzesień 16). Propaganda historyczna Rosji w latach 2004-2009. Pobrano 3 lipca 2017, z http://www.bbn.gov.pl/portal/pl/2/1840/Zaktualizowana_ wersja_analizy_BBN_quotPropaganda_historyczna_Rosji_w_latach_2004.html

Brügemann, K. (2008). Denkmäler des Grolls: Estland und die Kriege des 20. Jahrhunderts. Osteuropa, 58(6), 129-146.

Cornelißen, C. (2012). Erinnerungskulturen, Version: 2.0. W Docupedia-Zeitgeschichte. Pobrano 3 lipca 2017, z https://docupedia.de/zg/Erinnerungskulturen_Version_2.0_Christoph_ Corneli.C3.9Fen?oldid $=84892$

Czauderna, P. (2009). Sympozjum Dziedzictwo II wojny światowej z perspektywy 70 lat? w Europejskim Centrum Solidarności - relacja. Pobrano 3 lipca 2017, z http://ako.gdansk. pl/sympozjum-dziedzictwo-ii-wojny-swiatowej-z-perspektywy-70-lat-w-europejskimcentrum-solidarnosci-relacja/

Keghel, I. de. (2006). Abschied vom sowjetischen Gründungsmythos - Die Oktoberrevolution im Vergangenheitsdiskurs des spät - und postsowjetischen Russland. W B. Faulenbach \& F. J. Jelich (Red.), Transformationen der Erinnerungskulturen in Europa nach 1989 (ss. 227-252). Essen: Klartext Verlag.

Keghel, I. de. (2009). Verordneter Abschied von der revolutionären Tradition: Der „Tag der nationalen Einheit“ in der Russländischen Föderation. W L. Karl \& I. Polianski (Red.), Geschichtspolitik und Erinnerungskultur im neuen Russland (ss. 119-140). Göttingen: Vandenhoeck \& Ruprecht.

Korpela, J. (2008). Kijevo Rusia - istoriografinė fikcija? W A. Nikžentaitis, R. Petrauskas, \& M. Borgolte (Red.), Lietuvos vyriausybès susikūrimas europiniame kontekste (ss. 127-143). Vilnius: Lietuvos istorijos instituto leidykla.

Langenohl, A. (2000). Erinnerung und Modernisierung: Die öffentliche Rekonstruktion politischer Kollektivität am Beispiel des neuen Russland. Göttingen: Vandenhoeck \& Ruprecht.

Lutz-Auras, L. (2013). „Auf Stalin, Sieg und Vaterland!”: Politisierung der kollektiven Erinnerung an den Zweiten Weltkrieg in Russland. Wiesbaden: Springer VS. https://doi.org/10.1007/9783-658-00822-2

Michaleva, G. (2009). Vergangenheitsbewältigung als Voraussetzung für die Modernisierung Russlands. Osteuropa, 59(7-8), 47-58.

Niedermüller, P. (2004). Der Mythos der Gemeinschaft, Geschichte, Gedächtnis und Politik im heutigen Osteuropa. W A. Corbea-Hoisie i in. (Red.), Umbruch im östlichen Osteuropa: Die nationale Wende und das kollektive Gedächtnis (ss. 11-27). Innsbruck: Studien Verlag.

Nikžentaitis, A., \& Čepaitienè, R. (2014). Denkmäler und Erinnerungsorte der Demokratie in Ostmitteleuropa nach 1989. W H. J. Veen \& V. Knigge (Red.), Denkmäler demokratischer Umbrüche nach 1945 (ss. 115-130). Köln: Böhlau. 
Plaggenborg, S. (Red.). (2002). Handbuch der Geschichte Russlands (T. 5, cz. 1). Stuttgart: Hiersemann.

Putin, V. (2014, marzec 18). Rede zum Anschluss der Krim und Sewastopols. Pobrano 3 lipca 2017, z https://www.eurasischesmagazin.de/ticker/Wladimir-Putin-zum-Anschluss-derKrim-Rede-im-Wortlaut-Volltext/121

Russland kämpft: Gesetz und Kommission gegen Geschichtsfälscher. (2009). Osteuropa, 59(7-8), 273-276.

Scherrer, J. (2009). Erinnern und Vergessen: Russlands Umgangs mit (seiner) Geschichte in einer europäische Perspektive. W L. Karl \& I. Polianski (Red.), Geschichtspolitik und Erinnerungskultur im neuen Russland (ss. 23-40). Göttingen: Vandenhoeck \& Ruprecht.

Sheliha, W. von. (2011). Der Pakt und seine Fälscher: Der geschichtspolitisches Machtkampf in Russland zum 70. Jahrestag des Hitler - Stalin Pakts. W A. Kaminsky, D. Müller, \& S. Troebst (Red.), Der Hitler-Stalin Pakt 1939 in der Erinnerungskulturen der Europäer (ss. 175-198). Göttingen: Wallstein.

Sygar, M. (2016). Endspiel: Die Metamorphosen des Wladimir Putin. Bonn: Bundeszentrale für politische Bildung.

Troebst, S. (2005). Postkommunistische Erinnerungskulturen im östlichen Europa: Bestandsaufnahme, Kategorisierung, Periodisierung / Postkomunistyczne kultury pamięci w Europie Wschodniej: Stan, kategoryzacja, periodyzacja. Wrocław: Wydawnictwo Uniwersytetu Wrocławskiego.

W Moskwie otworzono Muzeum Historii Gułagu. (2015, listopad 3). Pobrano 7 lipca 2017, z http://wiadomosci.onet.pl/swiat/w-moskwie-otworzono-muzeum-historii-gulagu/cnlfq4

Гизен, А. (2015). Расколотая память: Отражение конфликта вокруг „Мемориального центра Пермь-36” в российских медиа. Журнал исследований соииальной политики / The Journal of Social Policy Studies, 13(3), 363-376.

Гузенкова, Т. (2015). Историческая политика: Память прошлого как инструмент конструирования настоящего. W Т. Гузенкова (Red.), Наследники Победы и поражения: Вторая мировая война в исторической политике стран СНГ и ЕС (ss. 7-38). Москва: Издательство ФИВ.

Ефремова, В. (2013). День народного единства: Изобретение праздника. W О. Малинова (Red.), Символическая политика: Сz. 1. Конструирование представлений о прошлом как властный ресурс. Москва: ИНИОН РАН.

Исаев, Е. (2015). Историческая политика в России: Репрезентация сталинской эпохи в популярном кинематографе. Журнал исследований соииальной политики / The Journal of Social Policy Studies, 13(3), 391-406.

Колеров, М. (2014). „Историческая политика” в современной России: Поиск институтов и языка. W Русский сборник: Исследования по истории России (Т. 16, ss. 441-480). Москва: Модест Колеров.

Копосов, Н. (2011). Память старого режима: История и политика России. Москва: Новое литературное обозрение. 
Лапин, В. (2016). Предисловие: Романовы, 400 лет бытования мифа. W В. Лапин \& Ю. Сафронова (Red.), 400-летие дома Романовых 1613-2013: Политика памяти и монархическая идея (ss. 7-22). Санкт Петербург: Издательство Европейского университета в СПБ.

Малинова, О. (2015). Актуальное прошлое: Символическая политика властвующей элиты и дилеммы российской идентичности. Москва: Политическая энциклопедия.

Мальцев, Д., Усова, Л., Сошин, Ю., \& Атаев, А. (2015). Отстаивая статус победителя. W Т. Гузенкова, Наследники Победы и поражения: Вторая мировая война в исторической политике стран СНГ и СЕ (ss. 41-95). Москва: Издательство ФИВ.

Миллер, А. (2012). Политические символы и историческая политика. W О. Малинова (Red.), Символическая политика: Сz. 1. Конструирование представлений о прошлом как властный ресурс (ss. 164-174). Москва: ИНИОН РАН.

Миллер, А. (2015). Политика памяти в России: Роль экспертных сообществ. W О. Малинова (Red.), Символическая политика: Cz. 3. Политические функиии мифов (ss. 210-235). Москва: ИНИОН РАН.

Нарочницкая, Н. (Red.). (2009). Партитура Второй мировой: Кто и когда начал войну? Москва: Вече.

Ожиганова, А., Кузнечевский, В., \& Филянова, В. (2012). Россия: Наследники Великой победы. W „Расскажу вам о войне ...” Вторая мировая и Великая Отечественная войны в учебниках и сознании школьников славянских стран (ss. 25-48). Москва: Издательство РИСИ.

Пихоя, Р. (2007). Москва, Кремль, власть: Две истории одной страны: Россия на изломе тысячелетий 1985-2005. Москва: Русь-Олимп-АСР-Астрель.

Селюнин, В. (1988). Истоки. Новый мир, 1988(5), 162-189.

Соцков, Л. (Red.). (2009а). Прибалтика и геополитика: 1935-1945. Москва: РИПОЛ классик.

Соцков, Л. (Red.). (2009b). Секреть польской политики: Сборник документов (1935-1945). Москва: РИПОЛ классик.

Торбаков, И. (2013). „Непредсказуемое” или „неопределенное” прошлое? Международные отношения и российская историческая политика. W O. Малинова (Red.), Символическая политика: Cz. 1. Конструирование представлений о прочлом как властный ресурс (ss. 91-125). Москва: ИНИОН РАН.

Шерлок, Т. (2014). Исторические нарративы и политика в Советском Союзе и постсоветской России. Москва: Российская политическая энциклопедия.

Шнирельман, В. (2011). Президенты и археология, или что ищут политики в древности. W И. Герасимов, М. Могильнер, \& А. Семенов (Red.), Империя и нация в зеркале исторической памяти (ss. 357-405). Москва: Новое издательство. 


\section{Bibliography (Transliteration)}

Altrichter, H. (2004). “Der Große Vaterländische Krieg”: Zur Entstehung und Entsakralisierung eines Mythos. In H. Altrichter, K. Herbers, \& H. Neuhaus (Eds.), Mythen in der Geschichte (pp. 471-494). Freiburg am Breisgau: Rombach.

Assmann, A., \& Shortt, L. (2012). Memory and political change. Basingstoke: Palgrave Macmillan UK. https://doi.org/10.1057/9780230354241

Assmann, J. (2000). Das kulturelle Gedächtnis: Schrift, Erinnerung und politische Identität in frühen Hochkulturen (3rd ed.). München: Beck.

Becker, A. (2016). Mythos Stalin: Stalinismus und staatliche Geschichtspolitik im postsowjetischen Russland der Ära Putin. Berlin: Be.bra Wissenschaft Verlag.

Biuro Bezpieczeństwa Narodowego. (2009, September 16). Propaganda historyczna Rosji w latach 2004-2009. Retrieved July 3, 2017, from http://www.bbn.gov.pl/portal/pl/2/1840/Zaktualizowana_wersja_analizy_BBN_quotPropaganda_historyczna_Rosji_w_latach_2004.html

Brügemann, K. (2008). Denkmäler des Grolls: Estland und die Kriege des 20. Jahrhunderts. Osteuropa, 58(6), 129-146.

Cornelißen, C. (2012). Erinnerungskulturen, Version: 2.0. In Docupedia-Zeitgeschichte. Retrieved July 3, 2017, from https://docupedia.de/zg/Erinnerungskulturen_Version_2.0_Christoph_Corneli.C3.9Fen?oldid=84892

Czauderna, P. (2009). Sympozjum Dziedzictwo II wojny światowej z perspektywy 70 lat? w Europejskim Centrum Solidarności - relacja. Retrieved July 3, 2017, from http://ako.gdansk. pl/sympozjum-dziedzictwo-ii-wojny-swiatowej-z-perspektywy-70-lat-w-europejskimcentrum-solidarnosci-relacja/

Efremova, V. (2013). Den' narodnogo edinstva: Izobretenie prazdnika. In O. Malinova (Ed.), Simvolicheskaia politika: Pt. 1. Konstruirovanie predstavlenĭ o proshlom kak vlastny resurs. Moskva: INION RAN.

Gizen, A. (2015). Raskolotaia pamiat': Otrazhenie konflikta vokrug “Memorial'nogo tsentra Perm'-36” v rossiǔskikh media. Zhurnal issledovaniŭ sotsial'noı̆ politiki / The Journal of Social Policy Studies, 13(3), 363-376.

Guzenkova, T. (2015). Istoricheskaia politika: Pamiat' proshlogo kak instrument konstruirovaniia nastoiashchego. In T. Guzenkova (Ed.), Nasledniki Pobedy i porazheniia: Vtoraia mirovaia voinna $v$ istoricheskoǐ politike stran SNG i ES (pp. 7-38). Moskva: Izdatel'stvo FIV.

Isaev, E. (2015). Istoricheskaia politika v Rossii: Reprezentatsiia stalinskoŭ èpokhi v populiarnom kinematografe. Zhurnal issledovaniŭ sotsial'noı̆ politiki / The Journal of Social Policy Studies, 13(3), 391-406.

Keghel, I. de. (2006). Abschied vom sowjetischen Gründungsmythos - Die Oktoberrevolution im Vergangenheitsdiskurs des spät - und postsowjetischen Russland. In B. Faulenbach \& F. J. Jelich (Eds.), Transformationen der Erinnerungskulturen in Europa nach 1989 (pp. 227-252). Essen: Klartext Verlag.

Keghel, I. de. (2009). Verordneter Abschied von der revolutionären Tradition: Der „Tag der nationalen Einheit“ in der Russländischen Föderation. In L. Karl \& I. Polianski (Eds.), 
Geschichtspolitik und Erinnerungskultur im neuen Russland (pp. 119-140). Göttingen: Vandenhoeck \& Ruprecht.

Kolerov, M. (2014). "Istoricheskaia politika” v sovremennoŭ Rossii: Poisk institutov i iazyka. In Russkiu sbornik: Issledovaniia po istorii Rossii (Vol. 16, pp. 441-480). Moskva: Modest Kolerov.

Koposov, N. (2011). Pamiat' starogo rezhima: Istoriia i politika Rossii. Moskva: Novoe literaturnoe obozrenie.

Korpela, J. (2008). Kijevo Rusija - istoriografinè fikcija? In A. Nikžentaitis, R. Petrauskas, \& M. Borgolte (Eds.), Lietuvos vyriausybès susikūrimas europiniame kontekste (pp. 127-143). Vilnius: Lietuvos istorijos instituto leidykla.

Langenohl, A. (2000). Erinnerung und Modernisierung: Die öffentliche Rekonstruktion politischer Kollektivität am Beispiel des neuen Russland. Göttingen: Vandenhoeck \& Ruprecht.

Lapin, V. (2016). Predislovie: Romanovy, 400 let bytovaniia mifa. In V. Lapin \& I. Safronova (Eds.), 400-letie doma Romanovykh 1613-2013: Politika pamiati i monarkhicheskaia ideia (pp. 7-22). Sankt Peterburg: Izdatel'stvo Evropeĭskogo universiteta v SPB.

Lutz-Auras, L. (2013). „Auf Stalin, Sieg und Vaterland!”: Politisierung der kollektiven Erinnerung an den Zweiten Weltkrieg in Russland. Wiesbaden: Springer VS. https://doi. org/10.1007/978-3-658-00822-2

Mal'tsev, D., Usova, L., Soshin, I., \& Ataev, A. (2015). Otstaivaia status pobeditelia. In T. Guzenkova (Ed.), Nasledniki Pobedy i porazheniia: Vtoraia mirovaia voĭna v istoricheskoŭ politike stran SNG i ES (pp. 41-95). Moskva: Izdatel'stvo FIV.

Malinova, O. (2015). Aktual'noe proshloe: Simvolicheskaia politika vlastvuiushche ̌̀ èlity i dilemmy rossiǔskoŭ identichnosti. Moskva: Politicheskaia èntsiklopediia.

Michaleva, G. (2009). Vergangenheitsbewältigung als Voraussetzung für die Modernisierung Russlands. Osteuropa, 59(7-8), 47-58.

Miller, A. (2012). Politicheskie simvoly i istoricheskaia politika. In O. Malinova (Ed.), Simvolicheskaia politika: Pt. 1. Konstruirovanie predstavlenĭ o proshlom kak vlastny̌̆ resurs (pp. 164-174). Moskva: INION RAN.

Miller, A. (2015). Politika pamiati v Rossii: Rol' èkspertnykh soobshchestv. In O. Malinova (Ed.), Simvolicheskaia politika: Pt. 3. Politicheskie funktsii mifov (pp. 210-235). Moskva: INION RAN.

Narochnitskaia, N. (Ed.). (2009). Partitura Vtorŏ mirovoŭ: Kto i kogda nachal voŭnu? Moskva: Veche.

Niedermüller, P. (2004). Der Mythos der Gemeinschaft, Geschichte, Gedächtnis und Politik im heutigen Osteuropa. In A. Corbea-Hoisie et al. (Eds.), Umbruch im östlichen Osteuropa: Die nationale Wende und das kollektive Gedächtnis (pp. 11-27). Innsbruck: Studien Verlag.

Nikžentaitis, A., \& Čepaitienè, R. (2014). Denkmäler und Erinnerungsorte der Demokratie in Ostmitteleuropa nach 1989. In H. J. Veen \& V. Knigge (Eds.), Denkmäler demokratischer Umbrüche nach 1945 (pp. 115-130). Köln: Böhlau.

Ozhiganova, A., Kuznechevskiŭ, V, \& Filianova, V. (2012). Rossiia: Nasledniki Velikoĭ pobedy. In "Rasskazhu vam o voinne ..." Vtoraia mirovaia $i$ Velikaia Otechestvennaia voinny v uchebnikakh i soznanii shkol'nikov slavianskikh stran (pp. 25-48). Moskva: Izdatel'stvo RISI. 
Pikhoia, R. (2007). Moskva, Kreml', vlast': Dve istorii odnou strany: Rossiia na izlome tysiacheletiu 1985-2005. Moskva: Rus'-Olimp-ASR-Astrel'.

Plaggenborg, S. (Ed.). (2002). Handbuch der Geschichte Russlands (Vol. 5, part 1). Stuttgart: Hiersemann.

Putin, V. (2014, March 18). Rede zum Anschluss der Krim und Sewastopols. Retrieved July 3, 2017, from https://www.eurasischesmagazin.de/ticker/Wladimir-Putin-zum-Anschlussder-Krim-Rede-im-Wortlaut-Volltext/121

Russland kämpft: Gesetz und Kommission gegen Geschichtsfälscher. (2009). Osteuropa, 59(7-8), 273-276.

Scherrer, J. (2009). Erinnern und Vergessen: Russlands Umgangs mit (seiner) Geschichte in einer europäische Perspektive. In L. Karl \& I. Polianski (Eds.), Geschichtspolitik und Erinnerungskultur im neuen Russland (pp. 23-40). Göttingen: Vandenhoeck \& Ruprecht.

Seliunin, V. (1988). Istoki. Novyı̆ mir, 1988(5), 162-189.

Sheliha, W. von. (2011). Der Pakt und seine Fälscher: Der geschichtspolitisches Machtkampf in Russland zum 70. Jahrestag des Hitler - Stalin Pakts. In A. Kaminsky, D. Müller, \& S. Troebst (Eds.), Der Hitler-Stalin Pakt 1939 in der Erinnerungskulturen der Europäer (pp. 175-198). Göttingen: Wallstein.

Sherlok, T. (2014). Istoricheskie narrativy i politika v Sovetskom Soiuze i postsovetskoŭ Rossii. Moskva: Rossiǔskaia politicheskaia èntsiklopediia.

Shnirel'man, V. (2011). Prezidenty i arkheologiia, ili chto ishchut politiki v drevnosti. In I. Gerasimov, M. Mogil'ner, \& A. Semenov (Eds.), Imperiia i natsiia v zerkale istoricheskŏ pamiati (pp. 357-405). Moskva: Novoe izdatel'stvo.

Sotskov, L. (Ed.). (2009a). Pribaltika i geopolitika: 1935-1945. Moskva: RIPOL klassik.

Sotskov, L. (Ed.). (2009b). Sekrety pol'skoŭ politiki: Sbornik dokumentov (1935-1945). Moskva: RIPOL klassik.

Sygar, M. (2016). Endspiel: Die Metamorphosen des Wladimir Putin. Bonn: Bundeszentrale für politische Bildung.

Torbakov, I. (2013). "Nepredskazuemoe” ili "neopredelennoe” proshloe? Mezhdunarodnye otnosheniia i rossiǔskaia istoricheskaia politika. In O. Malinova (Ed.), Simvolicheskaia politika: Pt. 1. Konstruirovanie predstavleniı̌ o proshlom kak vlastnyı̆ resurs (pp. 91-125). Moskva: INION RAN.

Troebst, S. (2005). Postkommunistische Erinnerungskulturen im östlichen Europa: Bestandsaufnahme, Kategorisierung, Periodisierung / Postkomunistyczne kultury pamięci w Europie Wschodniej: Stan, kategoryzacja, periodyzacja. Wrocław: Wydawnictwo Uniwersytetu Wrocławskiego.

W Moskwie otworzono Muzeum Historii Gułagu. (2015, November 3). Retrieved July 7, 2017, from http://wiadomosci.onet.pl/swiat/w-moskwie-otworzono-muzeum-historii-gulagu/ cnlfq4 


\section{Kultura pamięci i polityka historyczna w dzisiejszej Rosji}

\section{Streszczenie}

Badania nad zagadnieniem kultury pamięci w Rosji i krajach ościennych ciągle trwają, dlatego nie można jeszcze mówić o ich podsumowaniu. Istnieją jednak przesłanki, by przedstawić pewne wnioski na ten temat.

1. Przeprowadzona analiza ukazuje, że przypadek Rosji wyraźnie przeczy poglądom tych teoretyków, którzy negują możliwość istnienia narodowej kultury pamięci.

Po skomplikowanym etapie transformacji postsowieckiej w Rosji kultura pamięci w 2005 roku nabrała konkretnych kształtów. W jej centrum znalazła się opowieść o imperium (dieržava), którego status powinna uznać także reszta świata. Podstawowym symbolicznym zasobem dla toposu silnego państwa rosyjskiego jest mit zwycięstwa w Wielkiej Wojnie Ojczyźnianej. Jednak w ostatnim czasie do wzmocnienia mitu centralnego aktywnie wykorzystuje się także selektywnie wybrane fakty $\mathrm{z}$ innych epok historycznych.

2. Symboliczne figury tworzącej się czy też już ukształtowanej kultury pamięci są w Rosji stale reinterpretowane. Także mit zwycięstwa po 1992 roku przeszedł kilka etapów transformacji: $w$ pierwszych latach prezydentury Borysa Jelcyna (do roku 1995) dominowały aktywne próby dekonstrukcji tego mitu, w latach 1995-2000 był on odnowiony, akcentowano przede wszystkim status rosyjskiego narodu jako niepokonanej ofiary. W latach 2000-2005 w centrum mitu znów usytuowano państwo, a w ostatnim czasie został on poddany instrumentalizacji i wykorzystany jako argument w konfrontacji Rosji z Zachodem. Po 2011 roku wyraźnie widać próby ilościowego rozszerzenia zasobu instrumentarium symbolicznego za pomocą aktywnego wykorzystania wybranych faktów $\mathrm{z}$ innych epok historycznych.

3. Choć w Rosji wyraźnie dominuje meganarracja imperialna (dieržava), to jednak ma ona swoją konkurencję. W Rosji nadal w silnej opozycji do mitu zwycięstwa pozostaje mit ofiary. Lata 2009-2013 wyraźnie pokazały żywotność pamięci o ofiarach stalinowskich. W tym sensie struktura pamięci Rosji, choć z pewnymi wyjątkami, może być porównywana do polskiej, jednocześnie różniąc się istotnie od niemieckiej, litewskiej czy białoruskiej. W tych krajach dobitnie wyrażona jest jedna kultura pamięci, choć jej treść zawiera różne wątki tematyczne. W kontekście regionalnym nie mieści się Ukraina, w której jednolita polityka pamięci jest wprawdzie formowana, ale to dopiero początek procesu.

Słowa kluczowe: kultura pamięci; upamiętnienia; polityka historyczna; Rosja; kult Stalina; mit Wielkiej Wojny Ojczyźnianej; Gułag (Główny Zarząd Poprawczych Obozów Pracy) 


\title{
Memory culture and historical politics in today's Russia
}

\begin{abstract}
Considering that other countries are still conducting their studies, it is too early to make conclusions and summarise the question of Russia's memory culture and historical politics. However, it is possible to share some insights concerning this topic:

(1) This analysis indicates that Russia's case is in stark contrast to the opinions of those theorists who negate the existence of national memory culture. In Russia, this culture began to materialise in 2005, after the complicated period of post-Soviet transformation. What became central was the narrative of the empire (derzhava), whose status should also be recognised by the rest of the world. The main symbolical resource used in the construction of the motif of powerful Russia is a myth of victory in the Great Patriotic War. More recently, however, this general myth has been strengthened by selected facts from other historical periods.

(2) Symbolical figures of Russia's memory culture - both those developing and those already formed - are continuously reinterpreted. Since 1992 the myth of victory has undergone a few stages of transformation: the first years of Boris Yeltsin's presidency (until 1995) were dominated by active efforts to deconstruct this myth; in the period between 1995 and 2000 it was restored, with a particular stress put on the status of Russian people as the unconquered victim; in 2000-2005, the State regained its vital place in the structure of the myth. Recently, the myth has been instrumentalised and used as an argument in Russia's confrontation with the West. The period since 2011 has seen a noticeable increase in attempts to expand the symbolic instrumentarium through active use of selected facts from other historical periods.

(3) Although what dominates in Russia is the imperial mega narrative (derzhava), there is also an alternative stream that makes a substantial opposition - the myth of a victim. The years 2009-2013 have shown us that the memory of Stalin's crimes is really strong. In this sense, the structure of memory in Russia, although with some exceptions, is comparable to the Polish one. On the other hand, substantial differences are noticed in comparison with Germany, Lithuania or Belarus. Those countries have only one memory culture, although with different topics included in the content. Ukraine remains beyond the regional context: even though the process of forming a single policy of remembrance is in place, it is only in its initial phase.
\end{abstract}

Keywords: memory culture; culture of remembrance; politics of memory (historical politics); Russia; Stalin's cult; myth of the Great Patriotic War; the Gulag (the Main Administration of Corrective Labour Camps and Settlements) 
Dr hab. Alvydas Nikžentaitis, Head of Research at the Lithuanian Institute of History, Vilnius. Doctoral dissertation: 1986 (Institute of History, Academy of Sciences), habilitation: 1999 (Vilnius University). Author of five monographs and over eighty scholarly articles. His research interests span the period from the Middle Ages to the twenty-first century; he has recently specialised in comparative memory studies in Central and Eastern Europe.

Bibliography (selected): Nuo Daumanto iki Gedimino. Ikikrikščioniškos Lietuvos visuomenès bruožai [From Daumantas to Gediminas: Features of pre-Christian society of Lithuania], Acta Historica Universitatis Klaipedensis, vol. 5, Klaipeda 1996; Witold i Jagiełlo: Polacy i Litwini we wzajemnym stereotypie [Vytautas and Jogaila: Poles and Lithuanians in mutual stereotype], Poznań 2000; Unie polsko-litewskie w kulturach pamięci Litwy [Polish-Lithuanian Unions in Lithuania's cultures of memory], in: Od Horodła do Horodła (1413-2013). Unia Horodelska - dzieje i pamięć, Zamość, Warszawa (Warsaw) 2013, 103-118; Vietoj ịvado: daugiasluoksnè atmintis. Miestas, valstybe, regionas [Instead of introduction: Multi-layer memory], in: Alvydas Nikžentaitis (ed.), Atminties daugiasluoksniškumas. Miestas, valstybè, regionas, Vilnius 2013, 7-18; Vilnius kaip simbolinè keturių tautų sostinè [Vilnius as a symbolic capital of four nations], in: ibid., 217-228; Atminties ir istorijos politika Lietuvoje [Politics of memory and history in Lithuania], in: ibid., 517-538; Geschichte und Instrument. Geschichte und Aussenpolitik in Osteuropa [History and instrument: History and foreign politics in Eastern Europe], Osteuropa, 2010, Jg. 60, H 8, 105-112.

Correspondence: Alvydas Nikžentaitis, Lithuanian Institute of History, Vilnius, e-mail: alvydas. nikzentaitis@istorija.It

Support of the work: This article has been written under the research project "Modernisation of Identity?: Challenges of 'Europeanisation', Nationalism and Post-Sovietism for Memory Cultures" (No. MOD-17006), supported by the Research Council of Lithuania.

Competing interests: No competing interests have been declared. 